\title{
MORPHOLOGICAL EFFICACY EVALUATION OF GEL WITH CARBON DIOXIDE EXTRACT OF HOPS IN CASE OF COMPLICATED WOUND INFECTION ACNE VULGARIS
}

10.36740/WLek202101122

\author{
Tetiana M. Moiseienko', Inna I. Torianyk' ', Gennadiy Ye. Khrystian'1, Viktoria A. Rybak², Iryna A. Voronkina', \\ Anatoliy L. Melnyk ${ }^{3}$, Nina F. Merkulova ${ }^{4}$, Olena I. Mohylenets ${ }^{4}$, Ganna O. Solomennyk ${ }^{4}$, Natalia G. Popova ${ }^{4}$, \\ Victoria Yu. Ivannik', Mykhailo S. Myroshnychenko4 \\ 'STATE ENTERPRISE «INSTITUTE MICROBIOLOGY AND IMMUNOLOGY NAMED BY I.I. MECHNIKOV NATIONAL ACADEMY OF MEDICAL SCIENCES \\ OF UKRAINE», KHARKIV, UKRAINE \\ ${ }^{2}$ NATIONAL UNIVERSITY OF PHARMACY, KHARKIV, UKRAINE \\ 'ZAPORIZHZHIA STATE MEDICAL UNIVERSITY, ZAPORIZHZHIA, UKRAINE \\ ${ }^{4}$ KHARKIV NATIONAL MEDICAL UNIVERSITY, KHARKIV, UKRAINE
}

\begin{abstract}
The aim of the study is to reveal in the experiment the morphological features of the infected skin wounds healing, which are a manifestation of acne vulgaris severe and very severe forms, using a gel with carbon dioxide extract of hops.

Materials and methods: An experimental study was carried out on 80 male WAG rats of three months of age. The animals were divided into 9 groups. Group 1 consisted of intact animals $(n=6)$. Group 2 was represented by animals $(n=6)$, which had hair epilation on the dorsal surface of the body in an area of $1 \mathrm{~cm}^{2}$, followed by application of $2 \mathrm{ml}$ of placebo gel to this area. Group 3 included animals $(n=6)$, which were epilated on the dorsal surface of the body in an area of $1 \mathrm{~cm}^{2}$ and applied $2 \mathrm{ml}$ of $1 \%$ gel with carbon dioxide extract of hops. Group 4 included rats $(n=6)$, which were epilated on the dorsal surface of the body in an area of $1 \mathrm{~cm}^{2}$ and simulated thermal damage. Group 5 was represented by 10 rats, who were epilated on the dorsal surface of the body in an area of $1 \mathrm{~cm}^{2}$, simulated thermal damage, followed by applying $2 \mathrm{ml}$ of placebo gel to the wound surface. Group 6 included rats $(n=10)$, who underwent measures similar to group 5 , followed by application of $2 \mathrm{ml}$ of $1 \%$ gel with carbon dioxide extract of hops to the wound surface. In group 7, there were 6 rats, which were epilated on the dorsal surface of the body in an area of $1 \mathrm{~cm}^{2}$, thermal damage to the skin with underlying soft tissues was simulated, followed by application to the wound surface the reference strains of Staphylococcus aureus, Streptococcus pyogenes, Proteus vulgaris, Propionibacterium acnes, Escherichia coli, Pseudomonas aeruginosa, Malassezia slooffiae, Malassezia pachydermatis, Candida albicans, Candida parapsilosis. In groups 8 and 9, there were 15 rats each, which underwent measures similar to group 7, followed by applying $2 \mathrm{ml}$ of placebo gel on its surface on the next day after infection of the wound in group 8 , and in group $9-2 \mathrm{ml}$ of $1 \%$ gel with carbon dioxide extract hops. The material for the study was the skin with underlying soft tissues. It was used histological, histochemical, morphometric and statistical methods. Results: This experimentally created gel with carbon dioxide extract of hops activates separation processes of horny masses from the surface of the epidermis, cleaning the pores of the skin; stimulating the proliferative activity of the epidermis, which is located in the marginal sections of the wound or covers the surface of the regenerate; activating the processes of cleansing the wound from necrotic tissue; activating the growth and maturation of granulation tissue with its subsequent transformation into connective tissue. It has anti-inflammatory, bactericidal and antimycotic effects, normalizing skin microbiocenosis.

Conclusions: The complex morphological study has showed that gel with carbon dioxide extract of hops is a highly effective drug in treatment of severe and very severe acne vulgaris, characterized by the development of deep and infected wound defects.
\end{abstract}

KEY WORDS: morphology, complicated wound infection acne vulgaris, experiment, gel with carbon dioxide extract of hops

Wiad Lek. 2021;74(1):112-117

\section{INTRODUCTION}

Acne vulgaris is a widespread polyetiological disease of the skin (sebaceous glands and hair follicles) with a complex multifactorial development mechanism which has a pronounced effect on the psychosocial sphere and social adaptation of patients [1]. Acne ranks first in the structure of cosmetology pathology and third in the frequency of patients' referral to dermatological medical institutions [2].

Acne vulgaris manifests during puberty and worsens throughout adolescence. Epidemiological studies suggest that it can arise at any age [3]. The study of the Global Burden of Disease reported that acne vulgaris affects about $85 \%$ of young adults aged 12-25 years [4].

Acne, according to modern concepts, is considered as an inflammatory disease with a chronic recurrent course, characterized by hyperplasia of the sebaceous glands, hyperkeratosis and the formation of comedones - sebaceous-horny plugs in the ducts of the sebaceous glands with partial or complete blockage, as well as increased production of altered sebum composition [1]. 
Table 1. Components of the placebo gel and their ratio (weight percent)

\begin{tabular}{cc}
\hline Component & $\begin{array}{c}\text { Component ratio } \\
\text { in weight percent }\end{array}$ \\
\hline Ethanol $96 \%$ & $2.500-7.500$ \\
\hline Propyleneglycol & $5.000-15.000$ \\
\hline Polyethyleneglycol 400 & $5.000-15.000$ \\
\hline Carbomer (carbopol) & $0.600-0.800$ \\
\hline Sodium hydroxide & $0.070-0.120$ \\
\hline Trilon B & $0.025-0.075$ \\
\hline Purified water & Remainder
\end{tabular}

Table 2. Components of $1 \%$ gel with carbon dioxide extract of hops and their ratio (weight percent)

\begin{tabular}{cc}
\hline Component & $\begin{array}{c}\text { Component ratio } \\
\text { in weight percent }\end{array}$ \\
\hline Carbon dioxide hop extract & $0.500-1,500$ \\
\hline Ethanol 96\% & $2.500-7.500$ \\
\hline Propyleneglycol & $5.000-15.000$ \\
\hline Polyethyleneglycol 400 & $5.000-15.000$ \\
\hline Carbomer (carbopol) & $0.600-0.800$ \\
\hline Sodium hydroxide & $0.070-0.120$ \\
\hline Trilon B & $0.025-0.075$ \\
\hline Purified water & Remainder
\end{tabular}

Research has shown that inflammation precedes the formation of comedones and hyperkeratinization. Inflammation in the sebaceous hair follicle occurs even before the formation of rash elements and is manifested by a significant increase in the number of T-lymphocytes, macrophages, expression of interleukin 1 and alpha integrins. Interestingly, inflammatory changes are noted both in the place of subsequent formation of acne elements and in areas of healthy skin [5].

The pathogenetic factors of acne also include changes in the hormonal and immune status of the body, disorders of skin microbiocenosis $[6,7]$.

Studies have shown that the development and course of acne depends on a family (genetic) predisposition. There is a general pattern: the more often and more severe acne occurs in previous relatives, the more severe and torpid course of the disease will be in the next generation $[8,9]$.

Acne vulgaris is characterized by clinical diversity. According to the classification of the American Academy of Dermatovenereology, mild, moderate, severe and very severe degrees of severity of the disease are distinguished [10]. Also, acne is a chronic dermatosis, sometimes developing long-term non-healing wound defects and post-acne skin changes [2].

Despite the variety of approaches to acne vulgaris treatment with therapeutic and cosmetic means, this problem has not been completely solved [8]. P. Gibrad called acne one of the cornerstones, on which the efforts of physiologists, therapists and dermatologists are broken in the search for effective methods of treatment and explanation of the incomprehensible aspects of this disease [11]. Thus, the search for effective methods of treating this pathology remains an urgent issue for the medical community, which requires comprehensive clinical and experimental research.

\section{THE AIM}

The aim of the study is to reveal in the experiment the morphological features of the infected skin wounds healing, which are a manifestation of acne vulgaris severe and very severe forms, using a gel with carbon dioxide extract of hops.

\section{MATERIALS AND METHODS}

An experimental study was carried out on 80 male WAG rats of three months of age in the vivarium of the State Enterprise «Institute Microbiology and Immunology named by I.I. Mechnikov National Academy of Medical Sciences of Ukraine». The conditions of keeping and handling the animals were in accordance with the requirements of the «European Convention for the Protection of Vertebrate Animals used for Experimental and Other Scientific Purposes» (Strasbourg, 1986).

The animals were divided into 9 groups. Group 1 consisted of intact animals $(n=6)$. Group 2 was represented by animals $(n=6)$, which had hair epilation on the dorsal surface of the body in an area of $1 \mathrm{~cm}^{2}$, followed by application of $2 \mathrm{ml}$ of placebo gel to this area. Group 3 included animals $(n=6)$, which were epilated on the dorsal surface of the body in an area of $1 \mathrm{~cm}^{2}$ and applied $2 \mathrm{ml}$ of $1 \%$ gel with carbon dioxide extract of hops. Group 4 included rats $(n=6)$, which were epilated on the dorsal surface of the body in an area of $1 \mathrm{~cm}^{2}$ and simulated thermal damage. Group 5 was represented by 10 rats, who were epilated on the dorsal surface of the body in an area of $1 \mathrm{~cm}^{2}$, simulated thermal damage, followed by applying $2 \mathrm{ml}$ of placebo gel to the wound surface. Group 6 included rats $(n=10)$, who underwent measures similar to group 5 , followed by application of $2 \mathrm{ml}$ of $1 \%$ gel with carbon dioxide extract of hops to the wound surface. In group 7, there were 6 rats, which were epilated on the dorsal surface of the body in an area of $1 \mathrm{~cm}^{2}$, thermal damage to the skin with underlying soft tissues was simulated, followed by application to the wound surface the reference strains of Staphylococcus aureus (ATCC 25923), Staphylococcus aureus (ATCC 6538P), Streptococcus pyogenes (ATCC 19615), Proteus vulgaris (ATCC 4636), Propionibacterium acnes (ATCC 6919), Propionibacterium acnes (ATCC 11827), Escherichia coli (ATCC 25922), Pseudomonas aeruginosa (ATCC 27853), Malassezia slooffiae (CBS 7956), Malassezia pachydermatis (ATCC 14522), Candida albicans (ATCC 885-653), Candida albicans (Sklyar-31), Candida albicans (Sklyar-20), Candida parapsilosis (VKPGu 488/10). In groups 8 and 9, there were 15 rats each, which underwent measures similar to group 7 , followed by applying $2 \mathrm{ml}$ of placebo gel on its surface on the next day after infection of the wound in group 8 , and in group $9-2 \mathrm{ml}$ of $1 \%$ gel with carbon dioxide extract of hops. 
Characteristics of the placebo gel and $1 \%$ gel with carbon dioxide extract of hops are given in tables 1 and 2 .

Thermal damage of the skin with underlying soft tissues, as a characteristic complication of severe forms of acne vulgaris, was modeled using a contact burn method. A metal plate heated to $90^{\circ} \mathrm{C}$ was applied to a $1 \mathrm{~cm}^{2}$ skin area epilated on the dorsal surface of the body for 10 seconds.

Animals of groups 1-9 were withdrawn from the experiment on day 30 . The material for the study was the skin with underlying soft tissues. The material was fixed in $10 \%$ aqueous formalin solution on phosphate buffer ( $\mathrm{pH}$ - 7.0-7.2). The compaction of tissues fixed in formalin was achieved by conducting through alcohols of increasing concentration, Nikiforov's liquid (96\% alcohol and diethyl ether in a ratio of $1: 1$ ), chloroform and pouring into paraffin. Serial sections $4-5 \times 10^{-6} \mathrm{~m}$ thick were made from the blocks for staining with hematoxylin and eosin, picrofuxin according to van Gizon, according to Mallory.

Microspecimens were studied, using an Olympus BX-41 microscope (Japan) with subsequent processing with the Olympus DP-soft version 3.1 software. A morphometric study was carried out during which the thickness of the stratum corneum, epidermis, leukocyte-necrotic layer, demarcation leukocyte shaft, granulation tissue and connective tissue was measured.

A statistical analysis was performed using the Statistica 6.0 and Microsoft Excel 2003 software. When comparing the parameters, the nonparametric Mann-Whitney U-test was used. The significance of differences between the mean values of indicators in the groups was taken at a significance level of $\mathrm{p}<0.05$.

\section{RESULTS AND DISCUSSION}

In survey microscopy in rats of group 1, the skin, consisting of the epidermis and dermis, with the underlying hypodermis and muscle tissue, had a normal structure with the absence of any general pathological processes. Eosinophilic keratin masses were revealed on the epidermis surface, which braided their shafts at the points of hair exit. The average thickness of the epidermis and the layer of stratum corneum was $(20.11 \pm 0.69) \times 10^{-6} \mathrm{~m}$ and $(6.07 \pm 0.13) \times 10^{-6} \mathrm{~m}$, respectively.

In group 2, the skin with underlying hypodermis and muscle tissue had a structure similar to group 1 . The average values of the epidermis thickness and the layer of stratum corneum did not differ significantly $(\mathrm{p}>0.05)$ from the indicators of group 1 and were, respectively, $(19.79 \pm 0.52) \times 10^{-6} \mathrm{~m}$ and $(5.99 \pm 0.24) \times 10^{-6} \mathrm{~m}$. Our survey microscopy and morphometric study has showed that the placebo gel does not affect the morpho-functional state of the rat skin.

In rats of group 3, the skin with underlying soft tissues had a structure similar to that of group 1. In this group, the average value of the epithelial layer thickness did not differ significantly ( $p>0.05)$ from group 1 and amounted to $(19.58 \pm 0.42) \times 10^{-6} \mathrm{~m}$. The average value of the keratin masses layer thickness in this group was significant $(\mathrm{p}<0.05)$ lower value $\left((3.56 \pm 0.11) \times 10^{-6} \mathrm{~m}\right)$ compared to group 1 . The decrease in the thickness of the keratin mass layer on the epidermis surface, revealed by us during the morphometric study in group 2, was due to the use of gel with carbon dioxide extract of hops, which, from our point of view, activates the separation of horny masses from the skin surface.

Exfoliation of horny masses is known to cleanse the skin of exogenous toxins, allergens and pathogenic microorganisms. Constant replacement of «dead scales» with «new scales» in the stratum corneum helps to maintain aggression of the external environment [12].

In group 4, a survey microscopy revealed a wound cavity, its depth reaching the deep parts of the dermis and hypodermis. The wound cavity was filled with mature granulation tissue, which was characterized by a pronounced predominance of the fibrous component over the cellular and vascular components (figure 1). The fibrous component was characterized by the presence of thickened fuchsinophilic connective tissue fibers with different directions, among which collagen fibers predominated over elastic ones when stained according to Mallory. The cellular component was represented by macrophages, lymphocytes, fibroblastic cells and leukocytes. The vascular component was characterized by vessels of various sizes. The average value of the granulation tissue layer thickness was $(629.62 \pm 18.53) \times 10^{-6} \mathrm{~m}$. Behind the layer of granulation tissue, a layer of connective tissue was revealed, which, when stained with picrofuchsin according to van Gieson, was in some fields of view light red, and in another fields of view dark red. When stained according to Mallory, collagen fibers predominated over elastic fibers in the connective tissue, and in some of the visual fields the latter were not detected. The average value of the connective tissue layer thickness was $(134.29 \pm 11.08) \times 10^{-6} \mathrm{~m}$.

There was an increase in the proliferative activity of the epidermis in the marginal parts of the wound, which thickened and formed superficial acanthotic ingrowths in some of the visual fields. In some of them a thickened epithelial layer crawled to the surface of the granulation tissue but complete epithelialization of the wound did not occur. The average values of the epithelial layer thickness and the layer of stratum corneum, covering the surface of the epidermis, were $(22.12 \pm 0.67) \times 10^{-6} \mathrm{~m}$ and $(6.14 \pm 0.52) \times 10^{-6} \mathrm{~m}$, respectively. In this group in comparison with group 1 , the mean value of the stratum corneum layer thickness did not differ significantly ( $p>0.05)$, and the mean thickness value of the epidermis significantly $(\mathrm{p}<0.05)$ increased, which, in our opinion, was due to the regenerative activation of the proliferative potential of epithelial cells.

In group 5 there were revealed similar to group 4 features of the layers in the wound cavity and the marginal epidermis of the wound. During morphometry, it was found that the average values of the thickness of the stratum corneum, epithelial layer, granulation tissue layer, as well as the layer of connective tissue were, respectively, $(6.20 \pm 0.48) \times 10^{-6} \mathrm{~m}$, $(22.69 \pm 0.72) \times 10^{-6} \mathrm{~m},(612.15 \pm 20.09) \times 10^{-6} \mathrm{~m}$, $(139.52 \pm 10.11) \times 10^{-6} \mathrm{~m}$. Compared with group 1 , the aver- 


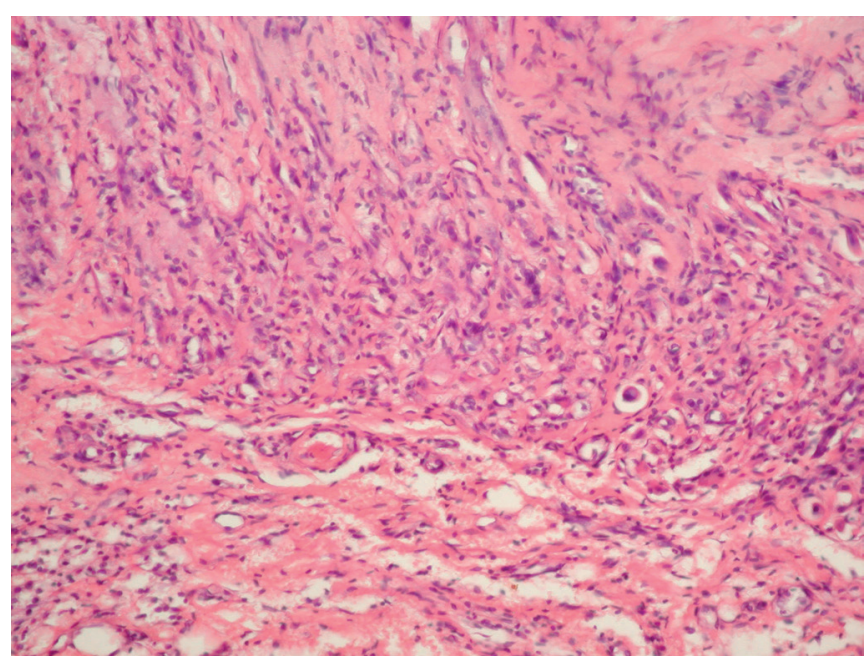

Fig. 1. Group 4. Mature granulation tissue, characterized by the predominance of the fibrous component over the cellular and vascular components. Stained with hematoxylin and eosin $\times 200$.

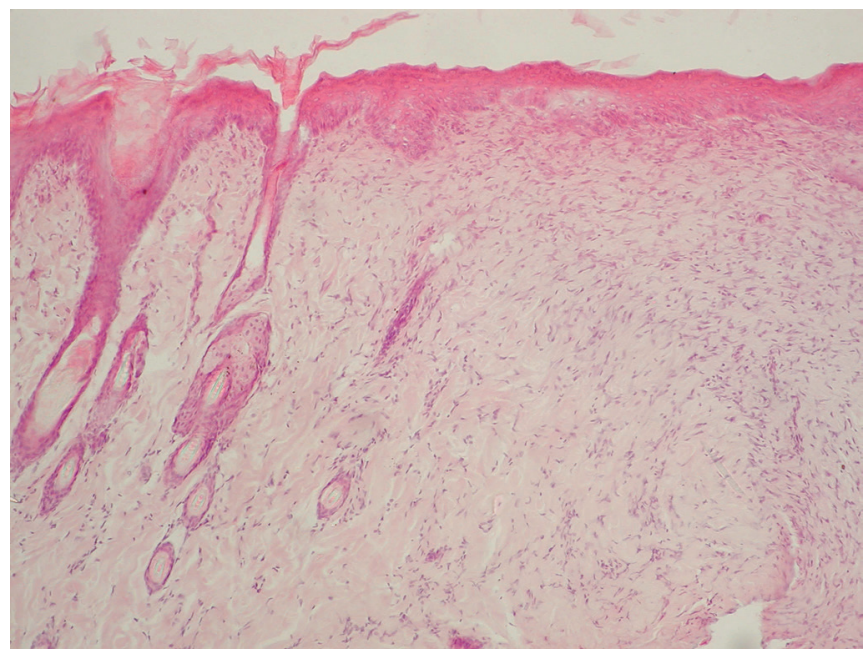

Fig. 3. Group 6. Formed regenerate with skin appendages. The surface of the regenerate is covered with thickened epidermis forming superficial and deep acanthotic ingrowths. Some horny masses on the surface of the epidermis. Stained with hematoxylin and eosin, $\times 100$.

age thickness values of the stratum corneum and epidermis did not have significant $(\mathrm{p}>0.05)$ differences. In this group, compared with group 4 , the average thickness values of a granulation tissue layer and connective tissue did not differ significantly $(p>0.05)$. Thus, a comparative analysis of the results obtained in groups 5 and 4 has showed that placebo gel does not have any effect on the healing processes of the experimental wound.

The survey microscopy in group 6 has revealed complete healing of the simulated wound defect in all animals. A regenerate represented by connective tissue in 6 rats, was determined in the area of the modeled defect, skin appendages were not detected in it. When stained with picrofuchsin according to van Gieson, the connective tissue fibers were located in different directions, were thickened, dark red color. Among connective tissue fibers, when stained according to Mallory, a pronounced pre-

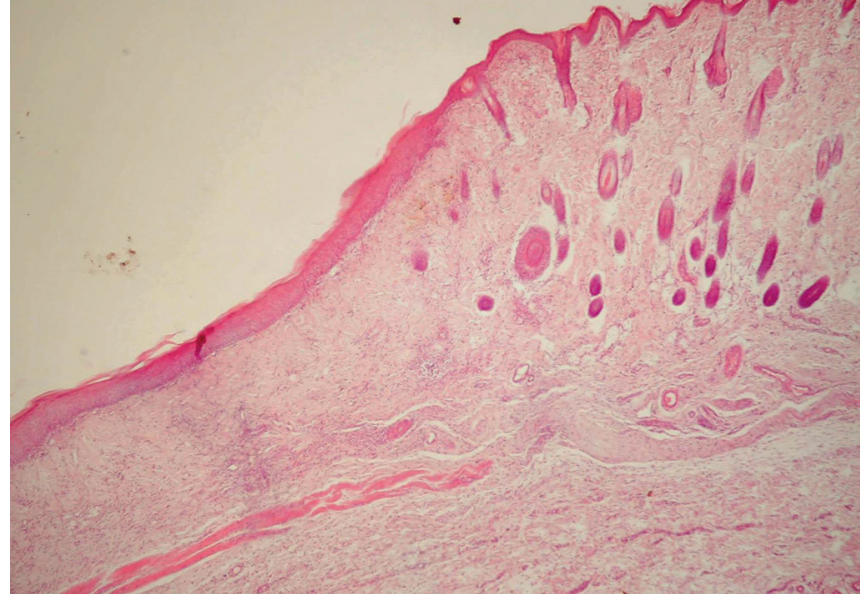

Fig. 2. Group 6. Atrophic skin scar. Some horny masses on the surface of the epidermis. Stained with hematoxylin and eosin, $\times 40$.

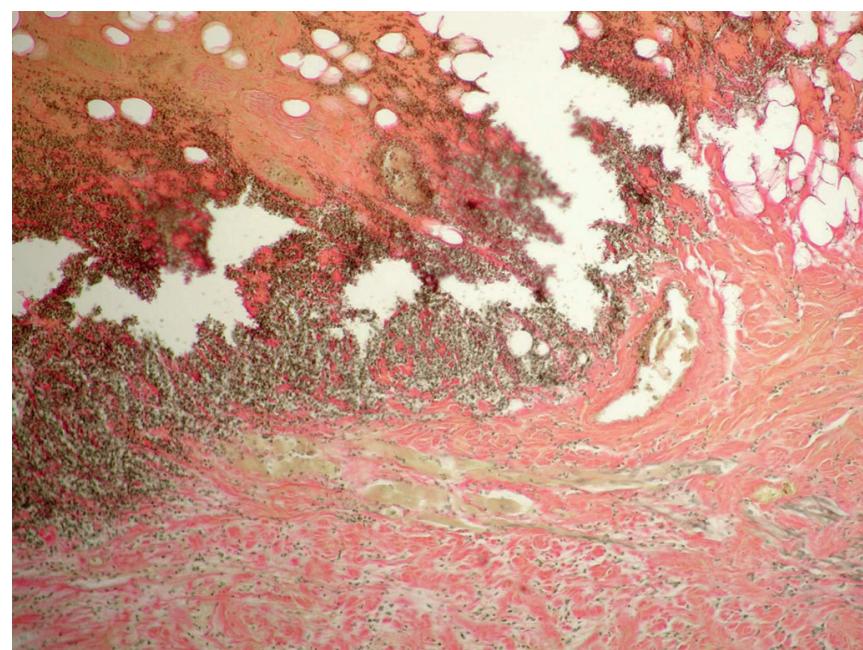

Fig.4. Group 7. Leukocyte-necrotic layer, demarcationzone, layer of granulation tissue in the wound cavity. Van Gieson's picrofuchsin staining, $\times 100$.

dominance of blue collagen fibers over red elastic fibers was determined, and the latter were absent in some of the visual fields. The surface of the regenerate was completely covered with a thickened epidermis.

It is interesting that in 2 rats of group 6 the connective tissue formed at the site of the wound defect, covered with the epidermis from the surface, was located below the surface of the surrounding skin, which corresponded to the structure of the atrophic skin scar (figure 2). In 4 rats, the formed connective tissue was located above the level of the surrounding skin surface, which indicated a hypertrophic scar formation.

In 4 rats of group 6, the connective tissue formed at the site of the wound defect was located at the level of intact skin, characterized by the presence of skin appendages, was covered with a thickened epidermis from the surface, which had a layer-by-layer organization, forming superficial and deep acanthotic ingrowths (figure 3). In the future, the latter will be the source of hair and gland buds formation [13]. The data obtained indicate the organotypic healing of the wound defect. 
Organotypic regeneration, as is known, is one of regeneration types when an organ defect is replaced by a regenerate corresponding to the organ's structure $[13,14]$.

In group 6, the average thickness value of the epidermis layer covering the surface of the regenerate had a significantly $(\mathrm{p}<0.05)$ greater value compared with groups 1 , 4,5 and amounted to $(26.75 \pm 0.74) \times 10^{-6} \mathrm{~m}$. The average thickness value of a stratum corneum layer located on the surface of the epidermis, covering the regenerate, in group 6 was $(3.12 \pm 0.24) \times 10^{-6} \mathrm{~m}$, which was significantly lower $(\mathrm{p}<0.05)$ compared with groups $1,4,5$. This fact, as in group 2, indicates that the gel with carbon dioxide extract of hops activates the separation processes of horny masses from the skin surface.

The average thickness value of a connective tissue layer in group 6 was $(726.18 \pm 44.35) \times 10^{-6} \mathrm{~m}$, which was significantly $(\mathrm{p}<0.05)$ higher compared to the same indicators in groups 4 and 5 .

A comparative analysis of the obtained data has showed that the gel with carbon dioxide extract of hops, firstly, intensifies separation processes of the horny masses from the epidermis surface; secondly, stimulates the proliferative activity of the epithelial layer of the skin, located in the marginal sections of the wound or covers the surface of the regenerate; thirdly, it activates the growth processes of granulation tissue and its transformation into connective tissue, leading to complete healing of the simulated wound of the skin with underlying soft tissues on the $30^{\text {th }}$ day of the experiment.

Observational microscopy in group 7 revealed a wound defect, the depth of which reached the dermis or hypodermis. The wound defect was characterized by a leukocyte-necrotic layer, represented by necrotic fragments of the epidermis and dermis with a large number of dead leukocytes (figure 4). This was followed by a demarcation leukocyte shaft, followed by a layer of granulation tissue with an underlying layer of connective tissue. The maturity of the granulation tissue varied. Thus, we noted predominance of the cellular and vascular components over the fibrous ones in the superficial sections of the granulation tissue adjacent to the demarcation zone and in the deep sections located closer to the layer of connective tissue the fibrous component dominated over the cellular and vascular ones.

In group 7, the average thickness values of the leukocyte-necrotic layer, demarcation zone, granulation tissue layer and connective tissue layer were, respectively, $(228.94 \pm 25.11) \times 10^{-6} \mathrm{~m},(149.15 \pm 11.22) \times 10^{-6} \mathrm{~m}$, $(319.58 \pm 19.56) \times 10^{-6} \mathrm{~m},(78.55 \pm 11.31) \times 10^{-6} \mathrm{~m}$.

The epithelial layer in the marginal sections of the wound was characterized by moderate dystrophic changes, in some visual fields it was thinned. Horny masses were found on the surface of the epidermis. The average thickness values of the stratum corneum and epidermis were $(6.87 \pm 0.92) \times 10^{-6} \mathrm{~m}$ and $(19.54 \pm 1.11) \times 10^{-6} \mathrm{~m}$

In a comparative analysis of the data obtained in group 7 compared with group 4 , it was found that the average value of the thickness of the epidermis significantly $(\mathrm{p}<0.05)$ decreased, the thickness of the stratum corneum layer did not change significantly ( $p>0.05)$, the average thickness values of the granulation tissue layer and connective tissue were significantly $(\mathrm{p}<0.05)$ smaller. Thus, the presence of infectious agents in the wound cavity inhibits proliferative processes in the epidermis located in the marginal sections of the wound; inhibits the cleansing of the wound from necrotic tissue; slows down the growth, maturation of granulation tissue and its transformation into connective tissue.

There are also numerous studies in the literature, confirming the presence of infectious agents in a wound as one of the factors, inhibiting reparative processes, leading to the emergence of long-term non-healing wounds that require long-term and complex treatment [15].

In group 8 , the survey microscopy and morphometric study did not reveal any differences from group 7, which once again proved that placebo gel did not have a wound healing effect. In this group, the average thickness values of the stratum corneum, epidermis, leukocyte-necrotic layer, demarcation zone, granulation tissue layer and connective tissue layer were $(6.79 \pm 0.61) \times 10^{-6} \mathrm{~m},(19.69 \pm 1.25) \times 10^{-6} \mathrm{~m}$, $(231.88 \pm 21.20) \times 10^{-6} \mathrm{~m},(151.22 \pm 10.15) \times 10^{-6} \mathrm{~m}$, $(322.64 \pm 17.71) \times 10^{-6} \mathrm{~m},(80.61 \pm 14.15) \times 10^{-6} \mathrm{~m}$.

Observation microscopy in group 9 revealed a wound cavity, the depth of which reached the dermis and hypodermis. It was filled with granulation tissue followed by a layer of connective tissue. It is interesting that the granulation tissue in the superficial sections was immature whereas in the deeper sections adjacent to the layer of connective tissue - mature.

The epidermis, located in the marginal parts of the wound, proliferated, formed superficial and deep acanthotic ingrowths into the underlying tissues, crawled to the surface of the granulation tissue. However, complete epithelialization of the wound was not detected. A few horny masses were found on the surface of the epidermis.

In this group, the average thickness values of the stratum corneum, epidermis, granulation tissue layer and connective tissue layer were, respectively, $(3.42 \pm 0.11) \times 10^{-6} \mathrm{~m}$, $(26.18 \pm 1.42) \times 10^{-6} \mathrm{~m},(452.29 \pm 21.95) \times 10^{-6} \mathrm{~m}$, $(101.19 \pm 17.74) \times 10^{-6} \mathrm{~m}$. Compared with groups 7, 8 in this group, the average thickness value of the layer of horny masses was significantly $(\mathrm{p}<0.05)$ smaller and the mean values of the epidermis thickness, the layer of granulation tissue and the layer of connective tissue had significantly $(\mathrm{p}<0.05)$ large values. Thus, the gel with carbon dioxide extract of hops not only activates separation processes of horny masses from the surface of the epidermis, stimulates the proliferative activity of the epidermis, activates the growth and maturation of granulation tissue with its subsequent transformation into connective tissue, which was shown in group 7, but also activates the processes of purification wounds from necrotic tissues, has an anti-inflammatory, bactericidal and antimycotic effect, normalizing skin microbiocenosis.

\section{CONCLUSION}

The complex morphological study has showed that gel with carbon dioxide extract of hops is a highly effective 
drug in treatment of severe and very severe acne vulgaris, characterized by the development of deep and infected wound defects. This experimentally created gel activates separation processes of horny masses from the surface of the epidermis, cleaning the pores of the skin; stimulating the proliferative activity of the epidermis, which is located in the marginal sections of the wound or covers the surface of the regenerate; activating the processes of cleansing the wound from necrotic tissue; activating the growth and maturation of granulation tissue with its subsequent transformation into connective tissue. It has anti-inflammatory, bactericidal and antimycotic effects, normalizing skin microbiocenosis.

\section{REFERENCES}

1. Sidorenko OA, Arkatova EA, Anisimova LA. Izuchenie mikrobioty kozhi u pacientok s pozdnimi akne pri lechenii preparatom azelainovoj kisloty [Skin microbiota in female late acne patients with azelaic acid preparation treatment]. Russian Journal of Clinical Dermatology and Venerology. 2019;18(5):599-606. (Ru)

2. Hubina-Vakulik HI, Bronova IM. Patogeneticheskaja terapija akne i patomorfologicheskie aspekty izmenenij kozhi v processe sanogeneza [Pathogenetic therapy of acne and pathomorphological changes in skin during sanogenesis]. Actual Problems of the Modern Medicine. 2017;17(2/58):98-107. (Ru)

3. Mohiuddin AK. A Comprehensive Review of Acne Vulgaris. Clinical Research in Dermatology. 2019;6(2):1-34.

4. Febyan, Wetarini K. Acne vulgaris in adults: a brief review on diagnosis and management. International Journal of Research and Review. 2020;7(5):246-252.

5. Snarskaya YeS, Medvedeva YaN. Vozmozhnosti kosmecevticheskih sredstv v topicheskoj terapii vulgarnyh akne [Possibilities of cosmetic products in topical therapy of acne vulgaris]. Dermatovenereology and dermatocosmetology. 2018;2:6-11. (Ru)

6. Lee YB, Byun EJ, Kim HS. Potential role of the microbiome in acne: a comprehensive review. Journal of Clinical Medicine. 2019;8:987. doi:10.3390/jcm8070987

7. Shupenko OM. Suchasni pogljady na problemu vugrovoi hvoroby ta perspektyvni shljahy podalshogo doslidzhennja patogenezu cogo dermatozu [Present-day views on the acne disease problem and prospective ways of the further studying of this dermatosis pathogenesis]. Dermatology. Cosmetology. Sexopathology. 2009;12(12):121-134. (Ua)

8. Averina VI, Salamova IV. Sovremennyj podhod k terapii vozrastnogo akne u zhenshhin [A modern approach to the treatment of age-related acne in women]. Medical Council. 2014;7:62-67. (Ru)

9. Heng AHS, Chew FT. Systematic review of the epidemiology of acne vulgaris. Scientific reports. 2020;10:5754. https://doi.org/10.1038/ s41598-020-62715-3

10. Snarskaya ES. Antibakterialnaja terapija vulgarnyh akne [Antibacterial therapy of vulgar acne]. Vestnik Dermatologii i Venerologii. 2019;95(5):58-67. (Ru)

11. Kogan BG, Verba EA. Novye podhody v kombinirovannom lechenii akne: vzgljad na problemu s tochki zrenija prakticheskogo zdravoohranenija [New approaches to the acne vulgaris treatment: problem from the health care point of view]. Ukrainian Journal of Dermatology, Venereology, Cosmetology. 2012;3(46):72-76. (Ru)
12. Murashkin NN, Ambarchyan ET, Epishev RV, Materikin Al. Barernye svojstva kozhi v norme i patologii. Barrier properties of the skin in health and disease. Pediatria. 2015;94(6):165-169. (Ru)

13. Bobr OA, Myadelets OD, Dubovskiy VV. Dinamika populjacii tuchnyh kletok $v$ techenii ranevogo processa u krys, podvergnutyh gipobioticheskim sostojanijam (golodanie, gipotermija) [The dynamics of the mast cell population during the wound process in rats subjected to hypobiotic conditions (starvation, hypothermia)]. Vestnik Vitebskogo gosudarstvennogo meditsinskogo universiteta. 2006;5(4):21-27. (Ru)

14. Vlasov 00, Kovalov G0, Myroshnychenko MS. Morphological assessment of wound healing after creodestruction of skin using an aqueous colloidal solution of C60 fullerenes. Wiadomości Lekarskie. 2020;73(4):642-647.

15. Negut I, GrumezescuV, Grumezescu AM. Treatment strategies for infected wounds. Molecules 2018;23(9):2392. doi:10.3390/molecules23092392

\section{ORCID and contributionship:}

Tetiana M. Moiseienko: 0000-0003-2069-9616 A,B,D

Inna I. Torianyk: 0000-0001-6843-8808 ${ }^{A, F}$

Gennadiy Ye. Khrystian: 0000-0003-0848-8023 C,F

Viktoria A. Rybak: 0000-0001-7649-4287 C,E,F

Iryna A. Voronkina: 0000-0002-2925-9601 B,E,F

Anatoliy L. Melnyk: 0000-0001-8378-3765 A,C,

Nina F. Merkulova: 0000-0001-7009-7272 B,E,F

Olena I. Mohylenets: 0000-0002-6217-9729 B, E

Ganna O. Solomennyk: 0000-0002-4864-9947 C,F

Natalia G. Popova: 0000-0002-2083-0402 A,C,E

Victoria Yu. Ivannik: 0000-0002-8688-6732 C,D,E,F

Mykhailo S. Myroshnychenko: 0000-0002-6920-8374 A,D,F

\section{Conflict of interest:}

The Authors declare no conflict of interest.

\section{CORRESPONDING AUTHOR Mykhailo S. Myroshnychenko}

Pathological Anatomy Department, Kharkiv National Medical University str. Svetlaya 27A, apt. 70, 61129, Kharkiv, Ukraine tel: $+380501699763,+380961033038$ e-mail: msmyroshnychenko@ukr.net

Received: 02.07.2020

Accepted: 23.12.2020

A - Work concept and design, B - Data collection and analysis, C - Responsibility for statistical analysis, D -Writing the article, $\mathbf{E}$-Critical review, $\mathbf{F}$ - Final approval of the article 